\title{
Operation of the EWS in the City of Matagalpa, Nicaragua
}

\author{
Marjorie Díaz-López ${ }^{*}$, Francisco Jiménez Otárola ${ }^{2}$ \\ ${ }^{1}$ Carrera de Ingeniería Forestal de la Universidad Nacional de Loja, Loja, Ecuador \\ ${ }^{2}$ Escuela de Posgrado del Centro Agronómico Tropical de Investigación y Enseñanza, Turrialba, Costa Rica \\ Email: *marjoriecristina1216@gmail.com
}

Received 28 November 2015; accepted 22 February 2016; published 25 February 2016

Copyright (C) 2016 by authors and Scientific Research Publishing Inc.

This work is licensed under the Creative Commons Attribution International License (CC BY). http://creativecommons.org/licenses/by/4.0/

(c) (i) Open Access

\section{Abstract}

The city of Matagalpa, due to the geological and morphological features of the territory, exposure to natural phenomena, the degradation of natural resources and rapid population growth, has endangered the welfare of its population, because of the high vulnerability and risk to the occurrence of natural disasters, principally flooding from the Grande Matagalpa River, which crosses through the center of the city, frequently leaving significant material damage and human loss. In this context, the initiative from the municipal government of Matagalpa to implement the "Rio Grande Matagalpa" project was born, financed by the European Cooperation, in order to initiate a process of flood risk management in the upper river basin and to strengthen and empower the population and the community in the prevention, mitigation and preparation against floods. As part of the project, the Joint Early Warning System (EWS) was designed, implemented and is currently operating, its purpose being to have available the information in real time, provided by automated tools and equipment, and monitored by local community organizations. The EWS is integrated into the risk management process which allows it to alert and communicate to the population about the possible occurrence of phenomenon possibly causing natural disasters, principally flooding in the city of Matagalpa.

\section{Keywords}

Risk Management, Flooding, Hydro Meteorological Events, Community, Institutional Organization, Natural Disasters

\section{Introduction}

The city of Matagalpa, Nicaragua is a territory very vulnerable to hydro meteorological threats. Some past "Corresponding author. 
events that have caused great damage are the passing of hurricanes Joan in 1988, Mitch in 1998 and Storm 36 in 2007. These events led to heavy rains which caused the overflowing of the Grande Matagalpa River, severe flooding and landslides in the city, significant material damage and loss of human life [1] [2].

Faced with these vulnerable scenarios, the Early Warning System (EWS) was born out of consideration for the necessity of a useful mechanism for risk management, since its implementation could alert and communicate to the population about the possible occurrence of phenomena that could cause natural disasters [3]-[5]. Furthermore, the EWS requires a technological component, the contribution and coordination of different social contributors, with functions and responsibilities ranging from knowledge of the risks, the vulnerabilities, the preparation and the responsiveness, to the community preparation, the institutional commitment to avoid or reduce the risk, and the preparation for an effective response [5]-[9].

The EWS includes three principle components: knowledge and mapping of threats, monitoring and forecasting of events, and processing and the announcement of alerts to the population. Based on this, the appropriate action for a timely response for proper management in a situation of crisis was agreed upon [3] [4]. This requires a fully adopted process of training, coordination and joint consultation made available to the institutions, organizations and the population at risk [3] [7].

The World Conference on Disaster Reduction held in Kobe, Japan in 2005 and the Third International Conference on Early Alert held in Bonn, Germany in 2006 led to significant advances in linking early warning with early action and risk reduction [7]. Moreover, emerging from this conference came initiatives for projects addressing problems and disasters in different parts of the world.

The municipal government of Matagalpa, accorded priority to the problem of the flooding caused by the river Grande of Matagalpa in its plan of action in 2009, this matter being attended through the international cooperation with financing by the European Cooperation of the "Rio Grande Matagalpa" project, which forms part of the VI Plan of Action DIPECHO (Disaster Preparedness of the European Commission's Humanitarian Aid Department) for Central America.

The goal of the project was to contribute to the reduction of risk by improving the preparation of the most vulnerable population in the areas most exposed to disasters in Matagalpa, through the joint strengthening of social skills and institutional preparation, prevention and mitigation, and the implementation of EWS [2]. The goal of this study was to analyze the EWS in the watershed Grande Matagalpa River.

\section{Methodology}

The city of Matagalpa (Figure 1) is located in the municipality of Matagalpa in the central region of Nicaragua. Geographically it lies between the coordinates $12^{\circ} 53^{\prime} 19^{\prime \prime}$ and $13^{\circ} 00^{\prime} 31^{\prime \prime}$ north latitude and $85^{\circ} 56^{\prime} 59^{\prime \prime}$ east longitude. The land area is $85.50 \mathrm{~km}^{2}$ and includes the urban area of Matagalpa, as well as the watershed communities of Molino Norte, San Francisco and Molá [10].

The methodology is based on qualitative research, starting with a literary review of information derived from the "Rio Grande Matagalpa" project, through reports, publications and research of the EWS. It was made from the identification of informants and key participants through their methodological identification nominal tools [11] [12]. After defining the reports and key community participants, individual semi structured interviews were applied [13].

In order to validate the information, focal groups [13]-[15] were recognized in the communities of Molino Norte, San Francisco and Molá with the participation of persons responsible for the carrying out and reading and the measurements of the instruments, and the direct beneficiaries of EWS, as well as the representatives of the Comité Local de Prevención, Atención y Mitigación a Desastres (COLOPRED), consisting of persons residing in the city of Matagalpa.

\section{Results and Discussion}

\subsection{Background EWS Matagalpa}

The geological and morphological characteristics of the municipal create favorable conditions for the risk of flooding. For example, Molino Norte, San Francisco and Molá are the principal head watersheds of the Grande Matagalpa River (Figure 2) and based on their morphometric features (Table 1), only the San Francisco watershed indicates a favorable form for a quick hydrological response. Moreover, the three watersheds present 


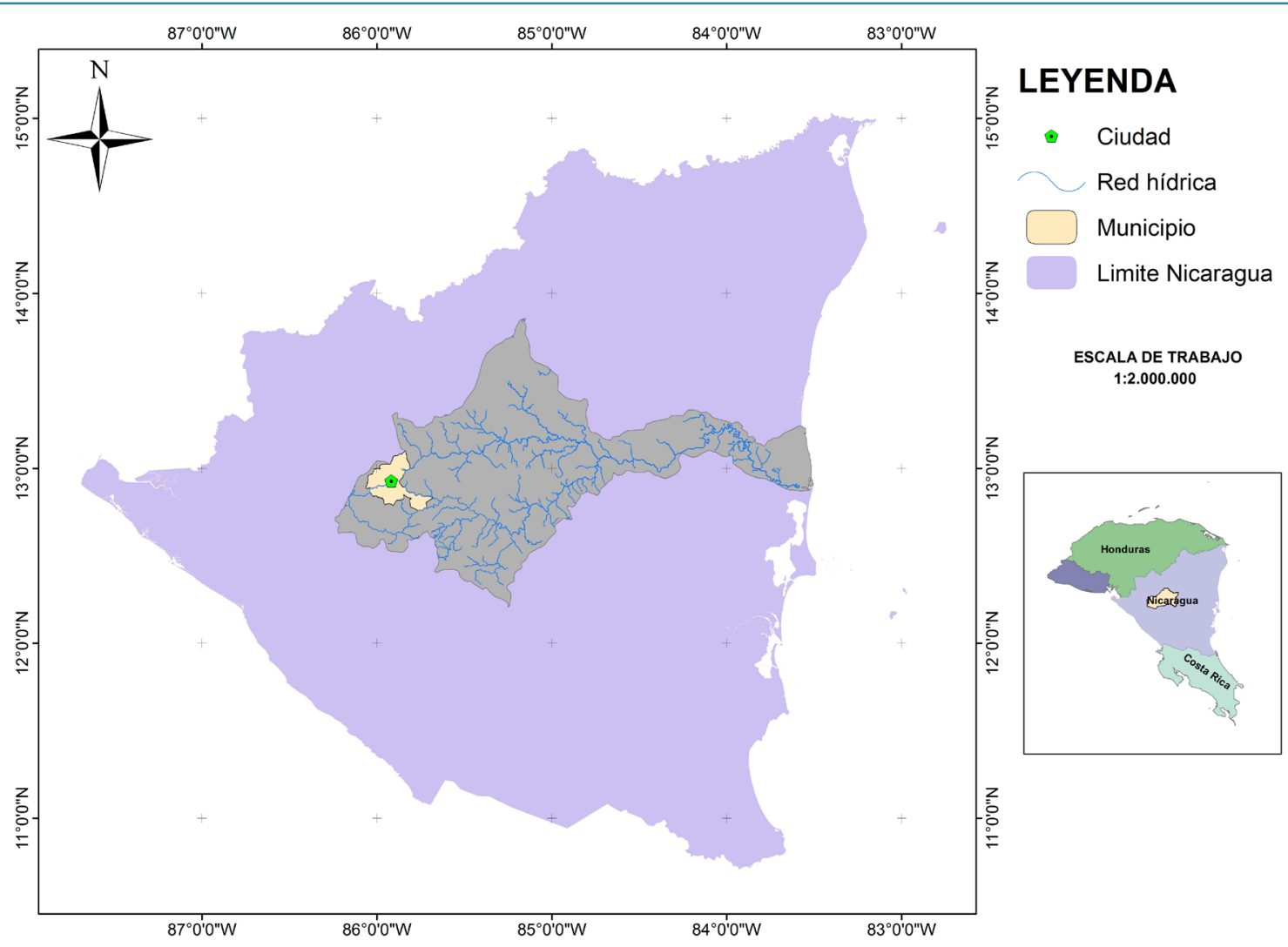

Figure 1. Location of the study area.

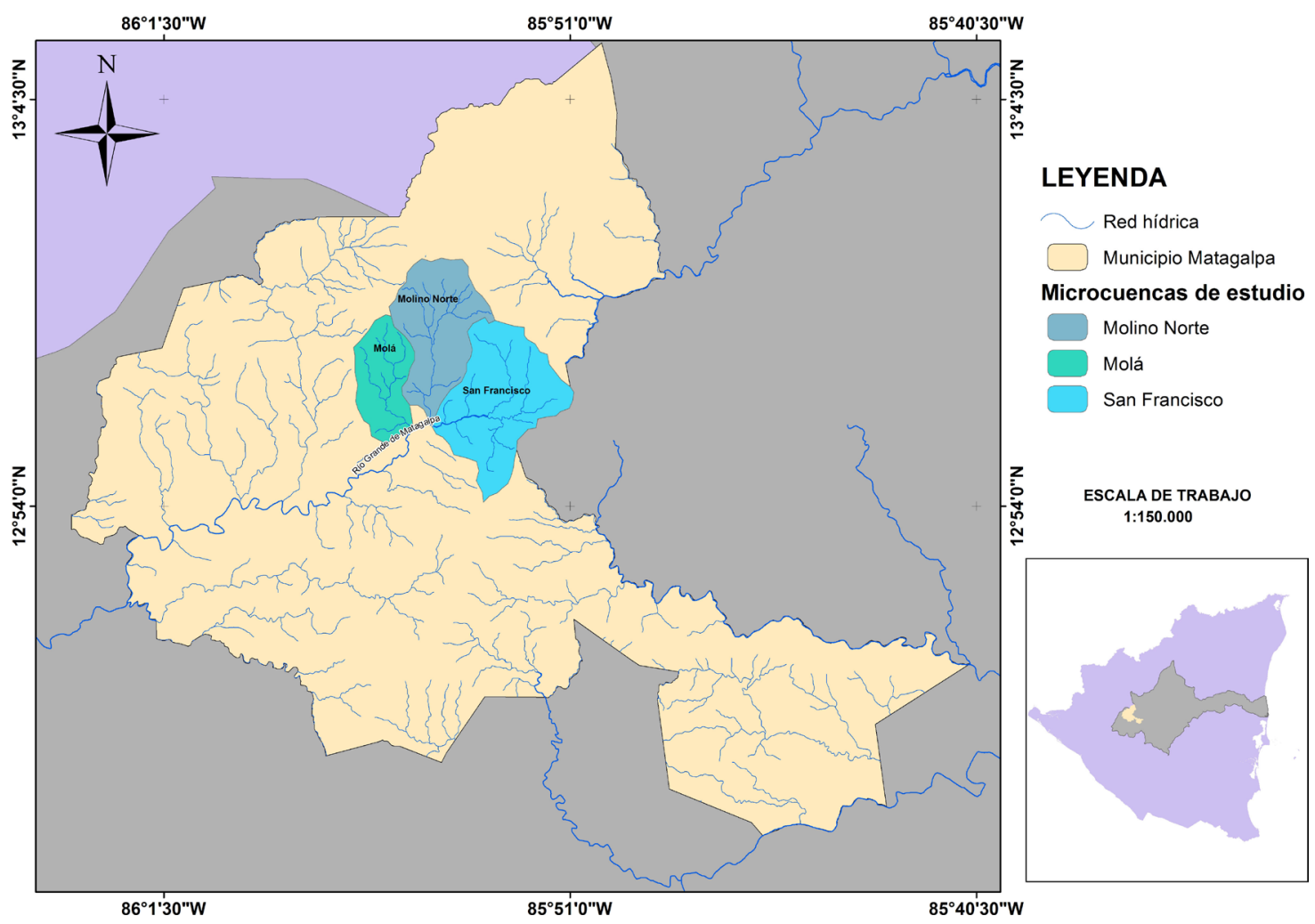

Figure 2. Principal watersheds of the Grande Matagalpa River. 
Table 1. Morphometric features of the principal watersheds.

\begin{tabular}{cccccc}
\hline \multirow{2}{*}{ Watersheds } & \multicolumn{5}{c}{ Morphometric features } \\
\cline { 2 - 6 } & Area $\left(\mathrm{km}^{2}\right)$ & Perimeter $(\mathrm{km})$ & Time of concentration (min) & Shape index & Average gradient \\
\hline Molino Norte & 21.83 & 24.41 & 68.28 & 0.61 & 25.68 \\
San Francisco & 29.49 & 28.72 & 48.76 & 1.32 & 23.30 \\
Molá & 12.65 & 17.76 & 40.18 & 0.51 & 24.85 \\
\hline
\end{tabular}

Source: [10].

times of very short concentration, which favor a level of rapid runoff that, in combination with the steep slope (which is directly related to the absorption and/or surface runoff), causes flash floods during events of precipitation.

Various authors [16]-[18] indicate that the morphometric features (form, gradient, density of drainage, etc.) and physiographic (localization and orientation) of a basin influence in the origin of floods, because they establish the form in which the water will run along the slopes.

Moreover, $78 \%$ of the watersheds' soils are clay loam and the remaining $17 \%$ are heavy clay soils, features that suggest that these areas have a low to medium absorption level, which, together with the features of a high slope of the hydrological units, high levels of superficial runoff are created [10].

The extraction of the sand bed from the Grande Matagalpa River, for construction material use, provokes changes in the speed and direction of the flow of water, facilitating and increasing the flood areas [10].

Adding to, this are the inadequate urban planning and population growth linked to social, political and economic problems, affecting a population highly vulnerable in social and physical terms. In Matagalpa, approximately $44.28 \%$ of the people live in extreme poverty, implying that people with fewer resources tend to settle in high risk areas, contributing to an increase in their vulnerability [2].

The deterioration of the environment, which is especially evident in the degradation of the watersheds, the climate variability, the lack of environmentally friendly practices and the lack of public awareness have favored an increase of hydro meteorological phenomena which have a negative impact on the infrastructure, therefore increasing the risk of flooding and landslides. In Matagalpa approximately $40.31 \%$ of the urban homes use wood for cooking and in rural areas approximately $92.36 \%$ use wood as the source of energy, exerting pressure on the natural resources, principally the vegetation [2] [10]. The deforestation, or the practices of logging, can reduce the capacity of water absorption of a forest, raising the runoff in the area [19].

Faced with this problem, the execution of the "Rio Grande Matagalpa” project arose, from which a process of formation and preparation of the population started, with the goal of contributing and reducing the risk for the most vulnerable population; also, the joint design, implementation and operation of EWS was proposed, with the goal of maintaining the population alerted of the possible occurrences of natural phenomena, specifically flooding.

\subsection{Beginning Stage of EWS}

\subsubsection{Participants in the Design and Implementation of EWS}

The municipal government was the institution that led the initial management process of EWS, through the implementation of the "Rio Grande Matagalpa" project. Given this commitment made by the municipality, the EWS design process was started, fulfilled through a collaborative process involving different institutional participants and organizations (Table 2).

The governmental participants coordinated and realized technical forums, while the non-governmental organizations underwent a timely exchange of experiences and knowledge; also contributing to the definition of adequate sites for the required communication network installation for the operation of EWS were the civil society institutions.

The implementation of the EWS equipment and instruments was the responsibility of the members of the "Rio Grande Matagalpa” project, the monitoring commission of COMUPRED and INETER.

This stage was successful, which in actuality had allowed the municipal to have a EWS, despite the difficulties presented, primarily because there was no previous experience in Nicaragua on the design of these systems for rapid runoff; adding to the instability of institutional volition, it was never made clear to some sectors their 
Table 2. Participants in the design and implementation of EWS.

\begin{tabular}{|c|c|}
\hline \multicolumn{2}{|l|}{ Government institutions } \\
\hline Instituto Nacional de Estudios Territoriales & INETER \\
\hline Alcaldía de Matagalpa & ALMAT \\
\hline Proyecto Río Grande & CRIC \\
\hline Ministerio del Ambiente y los Recursos Naturales & MARENA \\
\hline Ministerio Agropecuario y Forestal & MAGFOR \\
\hline Asociación de Municipalidades de Nicaragua & AMUNIC \\
\hline Instituto Nacional Forestal & INAFOR \\
\hline Comité Municipal de Prevención, Mitigación y Atención a Desastres & COMUPRED \\
\hline $\begin{array}{l}\text { Comité Local de Prevención, Mitigación y Atención a Desastres } \\
\text { Defensa Civil }\end{array}$ & COLOPRED \\
\hline \multicolumn{2}{|l|}{ Non-governmental organisms } \\
\hline \\
\hline \multicolumn{2}{|l|}{ OXFAM Internacional } \\
\hline Coordinadora Nacional para la Reducción de Desastres Guatemala & CONRED \\
\hline \multicolumn{2}{|l|}{ Civil society } \\
\hline Telecomunicaciones sin Fronteras & TSF \\
\hline Club de Radios Experimentadores de Nicaragua & CREN \\
\hline
\end{tabular}

participation and accompaniment of the process. Moreover, the very elevated costs created doubt, because at a national level there was only one provider of supplies, equipment and materials.

Nevertheless, the great political will on the part of the local government spared no efforts and resources in compliance with the Law 337 "Ley Creadora del Sistema Nacional para la Prevención, Mitigación y Atención a Desastres” (law establishing the Sistema Nacional de Prevención, Mitigación y Atención de Desastres) [20].

Studies realized by various authors [6] [21], prove that the development, design and implementation of an efficient EWS, require the contribution and coordination of a large variety of social participants with functions and assigned responsibilities.

\subsubsection{Design and Implementation of EWS}

The EWS is composed of a mixed system, comprised of automated measuring systems and community organization. The reason for this type of design of the EWS is for the natural conditions of the municipality and for the morphometric features present in the watersheds of Molino Norte, San Francisco and Molá.

The data generated from the automatic stations enables a prompt response in decision making, and the participation of the community organization allows the operation and sustainability of the EWS.

As part of the community alert system, the installation of artisanal level sensors in the watershed of each river was accomplished, accompanied by radios, located: 2 in Molino Norte, 1 in San Francisco and 1 in the city in the neighborhood of Pancasán.

Rain gauges were installed in the watersheds requiring the registration of its observers: 2 in Molá, 4 in Molino Norte and 5 in San Francisco. Of the 11 installed rain gauges in the watersheds, 5 have radios: 1 in Molá, 2 in Molino Norte and 2 in San Francisco. Similarly, 18 limnimetric rulers were installed, 14 distributed in Molino Norte and the rest in the city of Matagalpa.

Based on this design, the implementation of the EWS was accomplished. In the beginning, the producers of the communities were motivated to participate and begin a process of training and meetings in preparation for the reading and maintenance of instruments, as well as the handling of radios for the transmission of data.

As part of the automatic alert system, a telemetric rainfall station was installed in each watershed (Molá, Molino Norte and San Francisco) and a hydrometric-telemetric station was installed in the city.

The function of each rainfall station is to carry out a record of the precipitation in the aforementioned watersheds, while the telemetric stations send the data in real time, every five minutes, to the registration center which is installed in the Municipal Hall in the city of Matagalpa. The registration center stores and registers the sent data by telephone network (GPRS) and by radio communication.

If the amount of predicted rainfall exceeds the determined threshold (35 mm), messages will be sent to the Mayor, Vice-mayor, Departamento de Bomberos, Cruz Roja, Defensa Civil and COMUPRED via internet and SMS messages. There is a 5 minute lapse for the system to turn on the four sirens; in this short period of time 
the operator can review the incoming data, and if he or she does not cancel the order, the audible and visible alarms will be turned on by a switch via internet which will notify the population that it is at risk of flooding.

The mixed EWS is composed of four components (Figure 3): monitoring, prognosis, alert and response.

The first component is the monitoring stage, which consists of the reading of the rain gauges, sensors, level of the river, limnimeters, telemetric stations (rain gauge and hydrometric), with the respective stations of INETER, as well as VHF communication.

Continuing, we proceed to the prognosis stage of the hydro meteorological phenomena, where the data is recorded and registered, as well and further verified through VHF communication. Later, in the registration center, a review and analysis is undertaken. During this stage direct communication and coordination with the COMUPRED and the INETER is maintained. Also, once the data on the level of the river and the amount of rain is obtained, the level of warning is determined, and the information is transmitted to the vulnerable zones.

The alert stage is where the type of alert is declared, which can be: green, yellow or red, generating a warning and alarm to the public to take precautionary measures. If the situation so requires, an alert using the four sirens located in the city are activated, which also activates the mobilization of the COLOPRED. The conditions and features of the watersheds (Molino Norte, San Francisco and Molá) and the proximity of the city to the origin of these conditions should be noted by the municipality and the level of alert can pass directly to a green or red alert, or omitting the green and pass to yellow or red.

In the last stage of response the COMUPRED and COLOPRED activate their contingency and evacuation plans, respectively, with the purpose of reducing the negative impact that could cause flooding, as well as preventing the possible loss of human lives.

\subsubsection{Operation Protocol of EWS}

For the operation of EWS, two protocols have been established:

1) Routine operational protocol of EWS

Daily operation of the registration center: The registration center receives the data from the automatic stations, hydro meteorological data from the rain gauges, and sensors for the level of the river for its analysis. Moreover, it stores the data and verifies the predicted threshold for the alert, for which there exists an exclusive server, located in the registration center for the reception of data. From the registration center, a radio call is made to the rain gauge observers and sensors located at the river level. In case contact cannot be established, it can be reestablished with the support of the alternate base (Bomberos) in order to guarantee the proper operation of the equipment.

Maintenance of the monitoring equipment and communication radios: This stage consists, primarily, of verifying that the registration center receives the information from the automatic stations. It also guarantees the cleaning of the rain gauges and river level sensors, verifying their proper state of operation. Regarding the communication radios, it is necessary to keep a proper maintenance of the batteries, solar panels and other elements (cables and antennas).

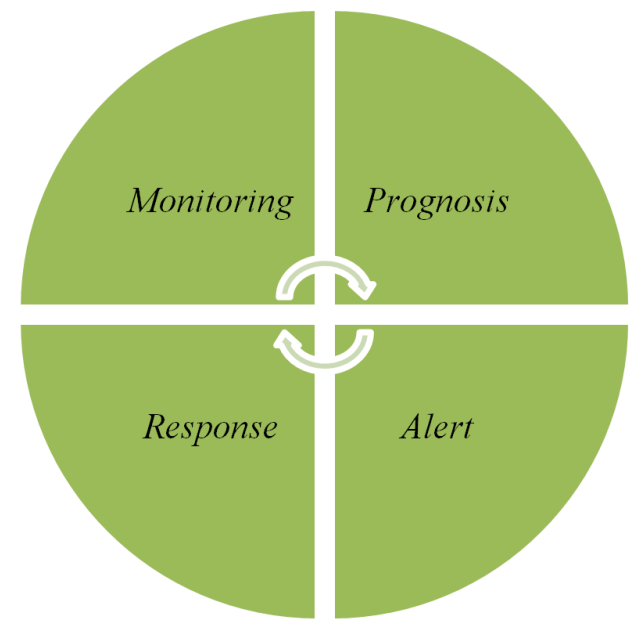

Figure 3. EWS components. 
Annual training of the personnel that make up the EWS: The EWS for floods is most effective mainly in the months of May to October (rainy season); with the month of January being suitable to plan the training process and evaluation of the system performance by the EWS operators.

Annual review and update of the municipal, neighborhood and communal emergency plan: Within this stage, a review of the plan should be conducted once a year by the representatives of the commissions of COMUPRED, as well as by members of COLOPRED and the Defensa Civil in order to be delivered to the appropriate authorities.

2) Operational protocol of the EWS in case of emergency

In the presence of phenomena, mainly hydro meteorological, it was considered important to establish and maintain an operational protocol for direct implementation during the presence of an emergency.

Tracking of a potential event (depression, storm, hurricanes, etc.):

First, a review of websites is done (www.ineter.gob.ni, www.noaa.com, www.huracan.net) and the monitoring commission of the COMUPRED prepares reports on the situation facing the municipality in the presence of rain.

Also, a local monitoring is performed with the information generated by the automatic stations as well as the monitoring of the rain gauges and river level sensors by radio communication. The time it takes for each of the volunteers to transmit the information is approximately 40 seconds, beginning with the reading of the rain gauges followed by the reading of the river level sensors. This information via radio will be repeated according to the magnitude of the event, every 12, 24, 45 minutes and every one to two hours.

In the case of the volunteers detecting a critical level of precipitation (three consecutive days of rain over 35 $\mathrm{mm}$ of precipitation or if it exceeds $35 \mathrm{~mm}$, which is the critical level) the registration center is notified immediately via radio. All this information is compared to the incoming information from the automatic stations. Once it passes the forecasted threshold $(35 \mathrm{~mm}$ ), the operator in the registration center has a time of 5 minutes in to cancel the order to sound the alarms, otherwise the alarms activate automatically.

Emission of alerts:

When issuing the alert the monitoring commission of the COMUPRED sends a report to the mayor, in which it declares the appropriate case: green, yellow or red alert for the municipality.

Current situation of the EWS:

The implementation and operation of the EWS has contributed to the creation of information for alerting and communicating to around 20,000 people, distributed to around 2900 families of urban neighborhoods and rural communities of the city of Matagalpa, who find themselves exposed mainly to flooding [10].

Despite the relatively high cost of maintenance of the hydro meteorological equipment (approximately US $\$ 1600$ annually, excluding investment costs for substitution of equipment failure, personnel costs, or organization and training of communities), this amount is relatively low compared to the benefits that the EWS provides, especially preventing the possible loss of human lives and contributing to minimize the economic costs of damage faced by many families in the post-disaster stage.

The EWS has been implemented exclusively for floods, but the multiple benefits that its operation actually provides is quite noticeable, both in the city and in the communities that inhabit the watersheds of Molino Norte, San Francisco and Molá: for example, the strengthening of the processes of organization, participation, decision making, assuming responsibilities and local empowerment.

Lessons learned from the EWS:

For the implementation and operation of a EWS, the organization and joint participation of various public and private institutions and of the civil society are indispensable.

- Sensitization and awareness from the authorities of the municipal government have been indispensable and have permitted the political and institutional support for the implementation of the EWS.

- Creation of institutional partnerships is needed in the design, implementation and operation of the EWS, as well as in the implementation of the proposed activities and actions.

- Training, preparation and exchange of experiences of the people in charge of the operation of the EWS have contributed to achieve an empowerment and participation.

- Political volition and stability have been fundamentals of the management of an EWS, which is led by the municipality.

- Trust and credibility of all the institutions for a good operation of a EWS and for promoting the participation of all the actors. 


\section{Conclusions}

In the municipality of Matagalpa, the EWS for floods has been designed, implemented and is currently operating, of which the management, collaboration, sensibilization and political volition of the local government, in addition to the joint participation of the public, private, civil and population sectors, to fundamentally carry out the realization of actions that contribute to inform the locality of the possible occurrence of natural phenomena.

To perform divulgation about the experience and lessons learned, from the management, design, implementation and operation of the EWS, as a means of consultation for others institutions involved in the risk management that can be utilized and implemented in other localities under their reality.

\section{Acknowledgements}

We would like to thank very much to CATIE FOCUENCAS II program for financial support and for the Municipal Government of Matagalpa and all the beautiful people Matagalpa. Thank you very much to our friends of CATIE FOCUENCAS Matagalpa and the Rio Grande Matagalpa project.

\section{References}

[1] Alcaldía Municipal de Matagalpa (ALMAT) (2004) Plan de respuesta municipal con enfoque de gestión del riesgo. Matagalpa.

[2] Organización para las Naciones Unidas para la Educación la Ciencia y la Cultura (UNESCO) (2012) Guía para la implementación y sostenibilidad de Sistemas de Alerta Temprana ante Deslizamientos (EWSD) en América Central: Fortalecimiento de los Sistemas de Alerta Temprana en América Central. San José.

[3] Zilbert, L. (2007) Sistemas de alerta temprana en el Caribe: Comunicación y divulgación: Guía de prácticas, herramientas y lecciones aprendidas: Reflexión sobre estudios de caso: Caribe anglófono, Cuba, Haití, y República Dominicana. Panamá.

[4] International Federation of Red Cross and Red Crescent Societies (IFRC) (2012) Community early warning systems: guiding principles. Geneva.

[5] Teisberg, T. and Weiher, R. (2009) Benefits and Costs of Early Warning Systems for Major Natural Hazards.

[6] Centro Regional de Información sobre Desastres para América Latina y el Caribe (CRID) (2009) Catálogo de herramientas y recursos de información sobre Sistemas de Alerta Temprana (EWS). San José.

[7] Federación Internacional de la Cruz Roja y la Media Luna Roja (IFRC) (2009) Informe mundial sobre desastres. Ginebra.

[8] Deutsche Gesellschaft für Internationale Zusammenarbeit (GIZ) (2012) Local Flood Early Warning System. Manila.

[9] Balzer, D., Jäger, S. and Kuhn, S. (2010) Manual para la Evaluación de la Exposición al Riesgo frente a Amenazas Naturales en Centroamérica.

[10] Escobar, E., López, N. and Baca, I. (2010) Estudios de riesgo a inestabilidad en laderas e inundaciones en la ciudad de Matagalpa y su entorno hidrográfico. Matagalpa.

[11] Chevalier, J. and Buckles, D. (2009) Guía para la Investigación Colaborativa y la Movilización Social. Plaza y Valdés, S.A. de C.V., México, D.F.

[12] Jiménez, F. (2009) Reconocimiento inicial de la cuenca e identificación y caracterización de actores claves. CATIE, Turrialba.

[13] Geilfus, F. (2002) 80 herramientas para el desarrollo participativo: Diagnóstico, planificación, monitoreo, evalución. Instituto Interamericano de Cooperación para la Agricultura, San José.

[14] Alberich, T., Arnanz, L., Basagoiti, M., Belmonte, R., Bru, P., Espinar, C., García, N., Habegger, S., Heras, P., Hernández, D., Lorenzana, C., Martín, P., Montañés, M., Villasante, T. and Tenze, A. (2009) Metodologías participativas. Madrid.

[15] Siles, J. and Soares, D. (2003) La fuerza de la corriente: Gestión de cuencas hidrográficas con enfoque de género. Editorial ABSOLUTO, San José.

[16] Villón, M. (2004) Hidrología. ITCR, Cartago.

[17] Muñoz, F. (2010) Manejo de Cuencas Hidrográficas Tropicales. Universidad Técnica Particular de Loja, Loja.

[18] Guariguata, M. and Kattan, G. (2002) Ecología y conservación de bosques neotropicales. Ediciones LUR, Cartago.

[19] Organización de los Estados Americanos (OEA) (2010) Manual para el diseño, instalación, operación y mantenimiento de sistemas comunitarios de alerta temprana ante inundaciones. OEA, Washington DC. 
[20] Sistema Nacional para la Prevención Mitigación y Atención a Desastres (SINAPRED) (2004) Plan de respuesta departamental con enfoque de gestión del riesgo Departamento de Matagalpa, Región VI. Managua.

[21] García, J., Ramírez, V., Julve, M., Gómez, A., Calderón, L., Izaguirre, A., Canales, E. and Villalobos, M. (2013) Informe sobre la gestión integral del riesgo de desastres en Nicaragua 2013. Managua.

\section{Abbreviations}

EWS: Early Warning System

DIPECHO: Disaster Preparedness of the European Commission's Humanitarian Aid Department for Central America. 